\title{
OPTIMIZATION OF EPOXIDATION PALM-BASED OLEIC ACID TO PRODUCE POLYOLS
}

\author{
Mohd Jumain Jalil1, ${ }^{凶}$, Nurul Hasna Asniera Rasnan², \\ Aliff Farhan Mohd Yamin ${ }^{2}$, Mohd Saufi Md Zaini ${ }^{3}$,Norhasimah Morad ${ }^{4}$, \\ Intan Suhada Azmi ${ }^{5}$, Mahazmi Burhanudin Mahadi', \\ Mohamad Zarqani Yeop
}

https://doi.org/10.23939/chcht16.01.066

\begin{abstract}
Optimization of epoxidation by using response surface methodology (RSM) based on three-level threefactorial central composite design (CCD) was used. Response percentage of relative oxirane content (\%RCO) was studied to determine the optimum reaction condition for production of polyols. The predicted value of model $(85 \%)$ was excellent in accordance to experimental value $(81 \%)$. All parameters (temperature, molar ratio of formic acid to oleic acid and molar ratio of hydrogen peroxide to oleic acid) were significant in influencing the course of epoxidation reaction $(p<0.05)$. The interaction between all parameters is also highly significant with $p<0.0001$. Optimum reaction conditions obtained from RSM were as follows: the temperature $318 \mathrm{~K}$, molar ratio of formic acid to oleic acid 1.64:1 and molar ratio of hydrogen peroxide to oleic acid 2:1. The epoxidation of palm oleic acid was carried out by using in situ performic acid. FTIR analysis showed the formation of epoxy functional groups at optimum reaction condition at the wavelength of $1340 \mathrm{~cm}^{-1}$. This epoxide group was used to produce polyols by using hydroxylation process and the polyols functional group was detected at the wavelength of $816 \mathrm{~cm}^{-1}$
\end{abstract}

Keywords: temperature, molar ratio, formic acid, hydrogen peroxide, epoxidation, polyols.

\footnotetext{
${ }^{1}$ School of Chemical Engineering, Universiti Teknologi MARA

Cawangan Pulau Pinang,

13500 Permatang Pauh, Pulau Pinang, Malaysia

${ }^{2}$ School of Mechanical Engineering, Universiti Teknologi MARA

Cawangan Pulau Pinang,

13500 Permatang Pauh, Pulau Pinang, Malaysia

${ }^{3}$ Faculty of Chemical Engineering, Universiti Teknologi MARA

Cawangan Terengganu,

Kampus Bukit Besi, 23200 Dungun, Terengganu, Malaysia

${ }^{4}$ School of Industrial Technology, Universiti Sains, Malaysia

${ }^{5}$ School of Chemical Engineering, Universiti Teknologi MARA

Cawangan Johor, 81750 Seri Alam, Johor, Malaysia

mjumain0686@uitm.edu.my

$\square$ Jalil, M.J.; Rasnan, N.H.A.; Yamin, A.F.M.; Zaini Md, M.S.;

Morad, N.; Azmi I.S.; Mahadi, M.B.; Yeop, M.Z., 2022
}

\section{Introduction}

Epoxide is a cyclic ether with three-membered ring, containing two carbon atoms and one oxygen. There are many sources that can be used to produce epoxide such as soybean oil, sunflower oil, palm oil, etc. ${ }^{1}$ There are two methods that can be used to produces epoxy groups such as epoxidation with halohydrins or molecular hydrogens and epoxidation with performic acid generated in situ or preformed. ${ }^{2}$ Performic acid generated in situ has been selected as an epoxidation process in this study since it is low in price and eco-friendly. In terms of application, it is used as plasticizer, for stabilization in polyvinyl chloride and intermediates product such as for polyols production. $^{3}$

Over the past decades, petrochemical-based raw material was used for polyols production. This raw material has economic and environmental challenges. The cost of its production is quite high. In addition, it also contributes to environmental problem such as air pollution. Currently, it has been notified that polyols also can be produced from vegetable oils like palm oil, soybean oil and rapeseed oil. Among these precursors, palm oil is one of the best oils to produce polyols because of availability of raw material, cost effectiveness and environmental friendliness. ${ }^{4}$ Polyols are an intermediate product vastly used in as pharmaceutical, food, polymer, and other industries. The major uses of polyols is in polymer industry where it is used in the production of polyurethanes (PU) such as foam, coating and elastomer. ${ }^{5}$ The common method of producing polyols are by transesterification of fatty acid, by hydroformylation, by oxidizing of olefin, epoxidation, and hydroxylation process from vegetables oil. ${ }^{6}$ In this study, epoxidation and hydroxylation methods were used to produce polyols due to high volume of production, fast reaction time, ecofriendliness, and low cost of production. ${ }^{7}$ 
Response surface methodology (RSM) is an optimization tool to evaluate the relative significance of several factors in the presence of complex interactions. It is a powerful technique for testing multiple-process variables with low number of experimental trials. RSM is able to determine the optimum levels of applied factors in order to obtain the desired (smallest or largest) value of the response function. ${ }^{8}$ In this study, CCD-RSM was used to study the optimum reaction conditions for epoxidation process to achieve high percentage of relative conversion of oxirane content (\% RCO). The parameters involved are the temperature, unsaturation molar ratio of formic acid to oleic acid and unsaturation molar ratio of hydrogen peroxide to oleic acid. The optimum reaction condition of epoxidized oleic acid was used for polyols formation.

\section{Experimental}

\subsection{Materials}

Palm-based oleic acid (75\%) was used as a raw material; hydrogen peroxide (30\%), formic acid $(85 \%)$, sulfuric acid $(95 \%)$, hydrogen bromide $(48 \%)$, glacial acetic acid (100\%), methanol and isopropanol (100\%), and crystal violet were purchased from Qrec Sdn Bhd.

\subsection{Epoxidation Process}

Epoxidation process was carried out in a $250 \mathrm{~mL}$ beaker with agitation speed of $1000 \mathrm{rpm}$ using magnetic stirrer. Oleic acid, formic acid or sulphuric acid were added as catalysts into a round bottom flask. The mixture was stirred continuously at fixed speed and gradually heated to required temperature and kept at constant temperature for the selected reaction time. The hydrogen peroxide was then added dropwise at desired temperature under continuous stirring. The samples were analysed by withdrawing approximately $5 \mathrm{~mL}(4-5 \mathrm{~g})$ of reaction mixture every $5 \mathrm{~min}$.

\subsection{Preparation of Polyol}

Hydroxylation process was carried out in a $250 \mathrm{~mL}$ beaker, similar to epoxidation process. $100 \mathrm{~g}$ of oleic acid was hydroxylated using a mixture of alcohols (methanol $25 \mathrm{~g}$ and isopropanol $25 \mathrm{~g}$ ). The reaction was conducted at the temperature of $338 \mathrm{~K}$, at $1000 \mathrm{rpm}$ for $2 \mathrm{~h}$. The reaction product (polyol) was analysed using FTIR to identify the presence of functional groups. The details of parameter involved and the reaction conditions of epoxidation process and polyols are given in Table 1. The experimental setup for epoxidation process and preparation of polyol can be seen in Fig. 1.

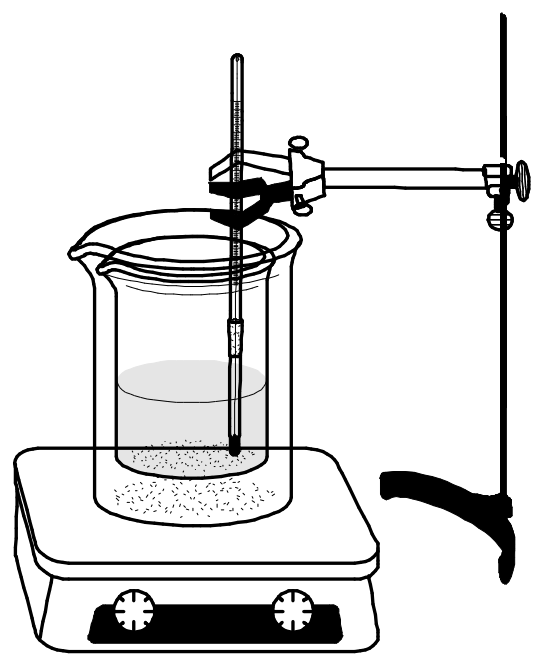

Fig. 1. Laboratory setup for epoxidation and polyols

Table 1. Experimental design for epoxidation and polyols

\begin{tabular}{|c|c|c|}
\hline Reaction parameter & Range & Units \\
\hline \multicolumn{3}{|c|}{ Epoxidation process } \\
\hline Temperature of oleic acid and hydrogen peroxide & $318-368$ & K \\
\hline Formic acid to oleic acid ratio & $1: 2$ & - \\
\hline Hydrogen peroxide to oleic acid ratio & $1: 2$ & - \\
\hline Agitation speed & 1000 & $\mathrm{Rpm}$ \\
\hline Reaction time & 45 & Minutes \\
\hline Catalyst (sulphuric acid) & $0.2-0.5$ & Gram \\
\hline \multicolumn{3}{|c|}{ Formation of polyols } \\
\hline Oleic acid epoxidation & 100 & Gram \\
\hline Methanol & 25 & Gram \\
\hline Isopropanol to oleic acid epoxidation & 25 & Gram \\
\hline Operating temperature for polyols & 338 & $\mathrm{~K}$ \\
\hline Reaction time for polyols & 2 & hours \\
\hline
\end{tabular}




\subsection{Determination of Experimental Oxirane Oxygen Content}

The experimental oxirane oxygen content was determined by following American Oil Chemists's Society 1997 (AOCS) Tentative method Cd 9-57. $10 \mathrm{~mL}$ of acetic acid were added into an Erlenmeyer flask and the mixture was shaked. Next, two drops of crystal violet indicator were dropped into the mixture. Then, the mixture was titrated under stirring with hydrogen bromide until bluish green colour was obtained and left for at least $30 \mathrm{~s}{ }^{9}$ The equation to calculate $\left(\mathrm{OOC}_{\text {exp }}\right)$ in moles per $100 \mathrm{~g}$ is given as follows:

$$
O O C_{\exp }=\frac{T \cdot N_{H B R} \cdot 1.6}{W}
$$

where $T$ is a volume of hydrogen bromide required to titrate the sample, $\mathrm{mL} ; N_{H B R}$ is a normality of the hydrogen bromide; $W$ is weight of the sample, $\mathrm{g}$.

From Eq. (1), the relative percentage conversion to oxirane content $(\% \mathrm{RCO})$ can be calculated through Eqs. (2) and (3).

$$
R C O=\frac{O O C_{\text {exp }}}{O O C_{\text {theor }}} \cdot 100 \%
$$

$O O C_{\text {theo }}=\left(I V_{\mathrm{o}} A / 2 A_{I}\right) /\left(250+\left(I V_{\mathrm{o}} A / 2 A_{I}\right) A_{\mathrm{o}}\right) \cdot A_{\mathrm{o}} \cdot 100$ (3) where $O O C_{\text {theor }}$ is a theoretically maximum oxirane oxygen content, $\mathrm{mg} / \mathrm{L} ; I V_{\mathrm{o}}$ is an initial iodine value of oleic acid sample; $A_{0}$ and $A_{I}$ are the molar masses of oxygen and iodine, respectively, $\mathrm{kg} / \mathrm{mol}$.

\subsection{Response Surface Methodology}

The three-level, three-factorial CCD experimental design with categorical factor was employed to study the effect of temperature, unsaturation molar ratio of formic acid to oleic acid, and unsaturation molar ratio of hydrogen peroxide to oleic acid based on the \% RCO (response). The design was composed of three levels (low, medium, and high), being coded as $-1,0$ and +1 . The total of 20 runs was carried out to optimize the level of chosen variables. For statistical computation, these variables were donated as A, $\mathrm{B}$ and $\mathrm{C}$, respectively, as tabulated in Table 2.

Table 2. Codes and actual levels of independent variables

\begin{tabular}{|l|c|c|c|}
\hline \multicolumn{1}{|c|}{ Symbols of independent variables } & \multicolumn{3}{c|}{ Coded levels } \\
\cline { 2 - 4 } & -1 & 0 & +1 \\
\hline A (temperature, C) & 45 & 70 & 95 \\
\hline B (unsaturation molar ratio of formic acid to oleic acid) & 1.0 & 1.5 & 2.0 \\
\hline C (unsaturation molar ratio of hydrogen peroxide to oleic acid) & 1.0 & 1.5 & 2.0 \\
\hline
\end{tabular}

Table 3. Central composite design (CCD) and its corresponding values

\begin{tabular}{|c|c|c|c|c|c|}
\hline \multirow{3}{*}{ Run order } & Factor 1 & Factor 2 & \multicolumn{2}{|c|}{ Factor 3 } & \multicolumn{2}{|c|}{ Response } \\
\cline { 2 - 6 } & Temperature* & $\begin{array}{c}\text { Molar ratio of formic } \\
\text { acid to oleic acid }\end{array}$ & $\begin{array}{c}\text { Molar ratio of hydrogen } \\
\text { peroxide to oleic acid }\end{array}$ & $\begin{array}{c}\text { \% RCO } \\
\text { (Actual) }\end{array}$ & $\begin{array}{c}\text { \%RCO } \\
\text { (Predicted) }\end{array}$ \\
\hline 1 & 70 & 1.5 & 2.0 & 55.1249 & 55.6552 \\
\hline 2 & 70 & 1.5 & 1.5 & 46.3768 & 47.6504 \\
\hline 3 & 70 & 2.0 & 1.5 & 36.7183 & 36.9313 \\
\hline 4 & 70 & 1.0 & 1.5 & 26.0480 & 25.0226 \\
\hline 5 & 45 & 1.0 & 1.0 & 30.7840 & 28.4976 \\
\hline 6 & 95 & 2.0 & 2.0 & 54.0000 & 52.0750 \\
\hline 7 & 95 & 1.0 & 1.0 & 50.2700 & 49.8491 \\
\hline 8 & 45 & 2.0 & 1.0 & 70.3297 & 70.2168 \\
\hline 9 & 95 & 2.0 & 1.0 & 57.6577 & 57.6302 \\
\hline 10 & 70 & 1.5 & 1.5 & 48.8596 & 47.6504 \\
\hline 11 & 45 & 1.0 & 2.0 & 59.4657 & 59.1410 \\
\hline 12 & 70 & 1.5 & 1.5 & 47.4047 & 47.6504 \\
\hline 13 & 70 & 1.5 & 1.0 & 42.8380 & 43.1111 \\
\hline 14 & 45 & 1.5 & 1.5 & 73.8817 & 73.1988 \\
\hline 15 & 70 & 1.5 & 1.5 & 48.9297 & 47.6504 \\
\hline 16 & 45 & 2.0 & 2.0 & 75.9794 & 75.177 \\
\hline 17 & 70 & 1.5 & 1.5 & 47.4074 & 47.6504 \\
\hline 18 & 95 & 1.5 & 1.5 & 71.8025 & 72.3234 \\
\hline 19 & 95 & 1.0 & 2.0 & 70.8749 & 69.9768 \\
\hline 20 & 70 & 1.5 & 1.5 & 46.7836 & 47.6504 \\
\hline
\end{tabular}

Note: temperature is in Celsius degree for calculations 


\section{Results and Discussion}

\subsection{Statistical Analysis}

\subsubsection{RSM model development}

In this research work, three operational parameter including temperature, unsaturation molar ratio formic acid to oleic acid and molar ratio of hydrogen peroxide to oleic acid have been chosen as operating variables and the percentage of RCO was the response. 20 sets of experiments were performed. The corresponding results of these experimental sets are summarized in Table 3.

Table 3 shows the different percentage of RCO obtained when varying level of parameters. Each of parameter affects the reaction condition and response. In this study, the highest percentage of RCO was $76 \%$ at the run order of 16 .

\subsubsection{Analysis of variance}

Analysis of variance (ANOVA) is a statistical method used to determine the differences among group means in the sample. ${ }^{9,10}$ The ANOVA results are tabulated in Table 4. The quadratic equation for predicting the optimum conditions was obtained from CCD-RSM and input variables. Thus, the empirical relationship between the response and independent variables is presented as Eq. (4):

$$
\begin{gathered}
\mathrm{Y}=-56.95-4.486 \mathrm{~A}+284.60 \mathrm{~B}+40.97 \mathrm{C}+ \\
+0.040762 \mathrm{~A}^{2}-63.93 \mathrm{~B}^{2}+6.46- \\
-0.6555 \mathrm{AB}-0.1738 \mathrm{AC}-23.65 \mathrm{BC}
\end{gathered}
$$

where $\mathrm{Y}$ is \% RCO (predicted), $\mathrm{A}, \mathrm{B}$ and $\mathrm{C}$ are temperature, molar ratio of formic acid, and molar ratio of hydrogen peroxide, respectively.

Table 4. Central composite design (CCD) and its corresponding values

\begin{tabular}{|c|c|c|c|c|c|c|}
\hline Source & Sum of square & $\mathrm{df}$ & Mean square & $F$-value & $p$-value & \\
\hline Model & 3773.92 & 9 & 419.32 & 597.84 & 0.000 & Significant \\
\hline Linear: & 735.13 & 3 & 245.04 & 349.36 & 0.000 & Significant \\
\hline $\mathrm{A}$ & 3.41 & 1 & 3.41 & 4.85 & 0.0052 & Significant \\
\hline $\mathrm{B}$ & 327.67 & 1 & 327.67 & 467.16 & 0.000 & Significant \\
\hline $\mathrm{C}$ & 404.06 & 1 & 404.06 & 576.07 & 0.000 & Significant \\
\hline Square: & 2184.37 & 3 & 728.12 & 1038.10 & 0.000 & Significant \\
\hline $\mathrm{A}^{2}$ & 1784.82 & 1 & 1784.82 & 2544.64 & 0.000 & Significant \\
\hline $\mathrm{B}^{2}$ & 702.50 & 1 & 702.50 & 1001.56 & 0.000 & Significant \\
\hline $\mathrm{C}^{2}$ & 7.18 & 1 & 7.18 & 10.23 & 0.000 & Significant \\
\hline Two-way interaction: & 854.42 & 3 & 284.81 & 406.05 & 0.000 & Significant \\
\hline $\mathrm{AB}$ & 537.04 & 1 & 537.04 & 765.67 & 0.000 & Significant \\
\hline $\mathrm{AC}$ & 37.78 & 1 & 37.78 & 53.86 & 0.000 & Significant \\
\hline $\mathrm{CC}$ & 279.60 & 1 & 279.60 & 398.62 & 0.000 & Significant \\
\hline Std. Deviation & 0.837498 & & & & & \\
\hline $\mathrm{R}^{2}$ & 0.9981 & & & & & \\
\hline Adjusted R & 0.9965 & & & & & \\
\hline Predicted $\mathrm{R}^{2}$ & 0.9946 & & & & & \\
\hline
\end{tabular}

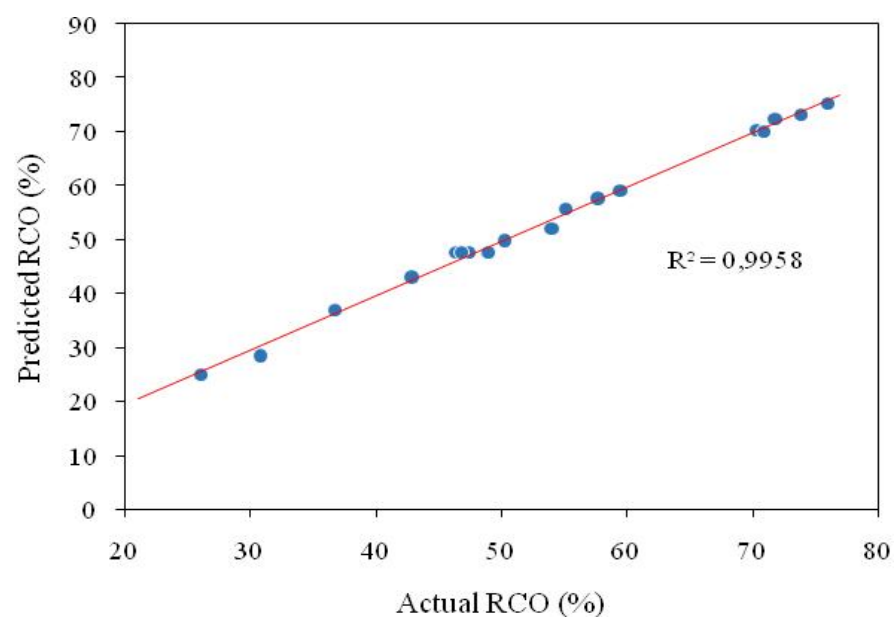

Fig. 2. Actual and predicted values for RCO percentage 
The ANOVA results referring to equation and actual relationship between the response and significant variables represented by the equation are accurate. The significance of the coefficient term is determined by the values of $F$ and $p$. The larger the value of $F$, the smaller the value of $p$, the more significant the coefficient. ${ }^{11}$ The linear model is statistically significant if $p$-value is less than 0.05 . Other than that, the square and two-way interactions model would be significance if $p$-value is less than $0.0001 .{ }^{12}$ From the results obtained in Table 4 , all the parameters in linear model are highly significance parameters with $p$-value less than 0.05. Among these control factors, parameter $\mathrm{C}$ (unsaturation molar ratio of hydrogen peroxide to oleic acid) is the most influential factor affecting the response. This is due to the largest number of $F$-value. These trends also work for square and two-way interaction models whereby all the parameters are regarded as highly significant because of $p$-value less than 0.0001 .

Fig. 2 shows the graph of actual and predicted value for percentage of RCO. This graph was analysed to examine the correlation between the actual and predicted responses. From the results it can be observed that the data points were well distributed close to straight line indicating the best fitting between the actual and predicted values of the response. The value of $\mathrm{R}$ is the variability between the actual value and predicted value. In this study, the value of $\mathrm{R}^{2}$ is 0.9958 which implies that $99.58 \%$ of actual data agreed well with the predicted data. ${ }^{13}$

\subsection{Interaction Effect Between Operating Parameters}

Fig. 3 shows the interaction between temperature (A) and molar ratio of hydrogen peroxide (C) towards the percentage of RCO. The optimization condition can be seen clearly at the contour plot graph. The smallest of $\% \mathrm{RCO}$ is referring to the clearest colour with percentage less than $50 \%$. Under this condition, temperature range and molar ratio of hydrogen peroxide are approximately $329-356 \mathrm{~K}$ and $1.0-1.68$, respectively. As reported by previous study, ${ }^{14}$ high operating temperature will contribute to low oxirane content and vice versa. This is because high temperature will promote the degradation of $\mathrm{RCO}^{15}$ It is also highlighted that molar ratio of hydrogen peroxide is one of the crucial factors that contributes to $\%$ RCO. It shows that when molar ratio of hydrogen peroxide increased, the \%RCO also improved progressively. However, the reaction becomes irreversible if the molar ratio content is too high. ${ }^{16}$ Referring to graph, the suitable operating temperature and molar ratio of hydrogen peroxide were $318 \mathrm{~K}$ and 2.0, respectively.

The effect of temperature and molar ratio of formic acid on \% RCO at constant molar ratio of hydrogen peroxide is shown in Fig. 4. As can be seen in contour plot, more than $70 \%$ of $\%$ RCO was achieved at $318 \mathrm{~K}$ of operating temperature and molar ratio of formic acid 1.64. As can be seen from this interaction, the smallest \%RCO is less than $30 \%$ within the range of operating temperature and molar ratio of formic acid of approximately $328-351 \mathrm{~K}$ and $1.0-1.03$, respectively. According to the results obtained by Lee et al. ${ }^{17}$ and Derouet et al., ${ }^{18}$ the highest molar ratio of formic acid results in higher formation of \%RCO. On the other hand, the trend is totally different with temperature, since low temperature is favourable for the formation of \% $\mathrm{RCO} .{ }^{19}$ This temperature is vital to achieves high oxirane content. It is also proven by statistical analysis (ANOVA) that when the $p$-value is less than 0.05 these parameters are significant to the response.

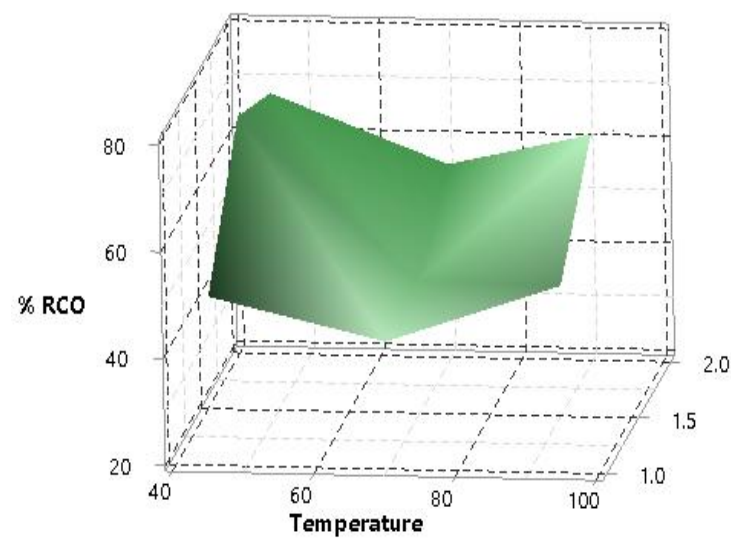

a)

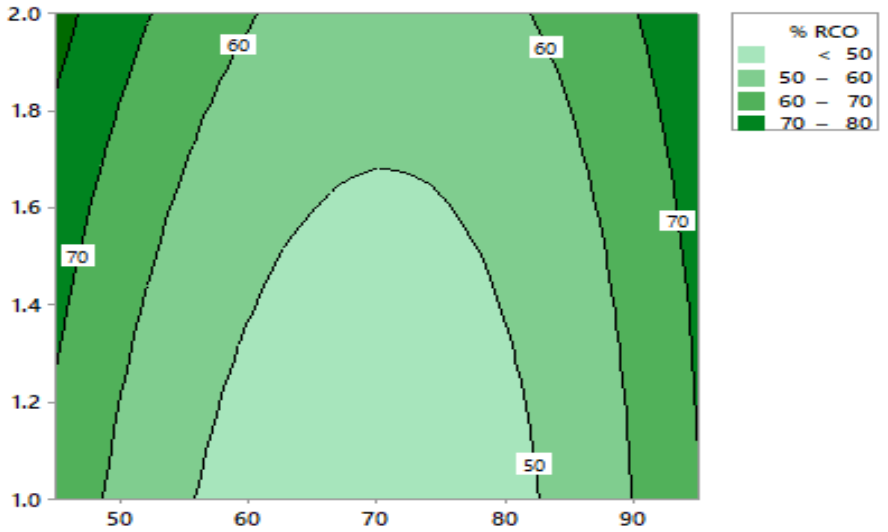

b)

Fig. 3. Three-dimensional (a) and contour (b) plots for interaction between temperature and hydrogen peroxide towards $\% \mathrm{RCO}$ 


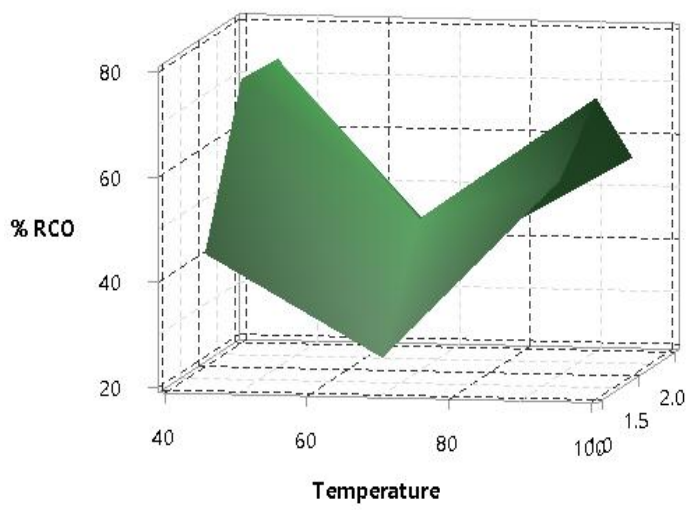

a)

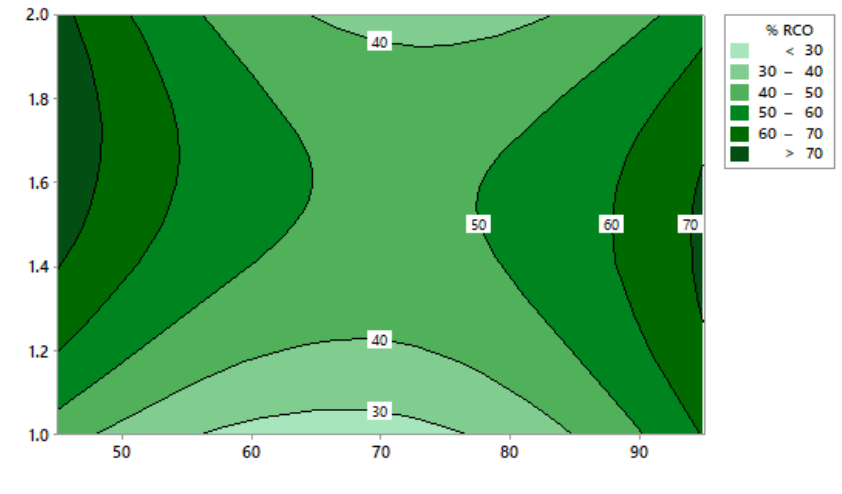

b)

Fig. 4. Three-dimensional (a) and contour (b) plots for interaction between temperature and formic acid towards $\%$ RCO

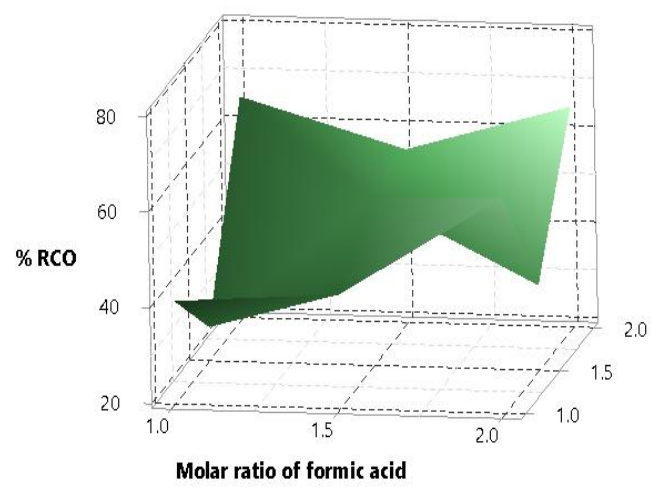

a)

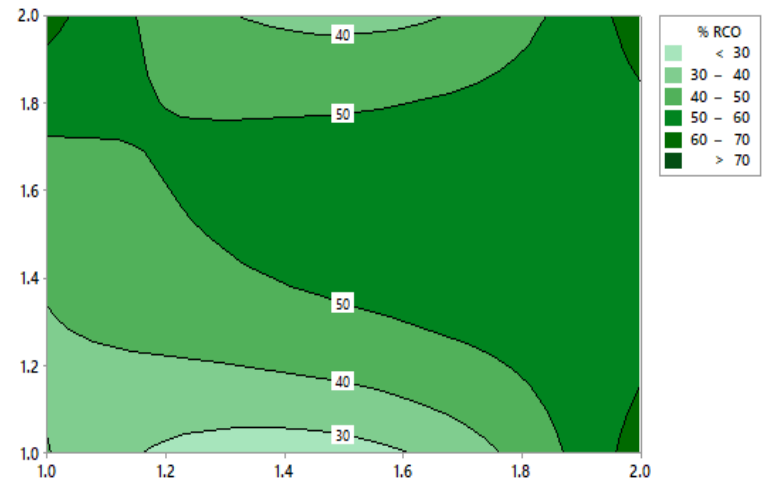

b)

Fig. 5. Three-dimensional (a) and contour (b) plots for interaction between molar ratios of formic and hydrogen peroxide towards $\% \mathrm{RCO}$

Fig. 5 indicates the interaction between molar ratio of formic acid and hydrogen peroxide towards \%RCO. Based on the graph, the suitable molar ratio for both parameters are in the range of $1.5-2.0$ at $318 \mathrm{~K}$ reaction temperature to obtain the \% RCO more than $70 \%$. Generally, higher molar ratio for hydrogen peroxide is pronounced to obtain high oxirane ring opening, which is slightly different with formic acid. ${ }^{20}$ Unlike hydrogen peroxide, the molar ratio of formic acid should be less than 2.0 in order to prevent instability of oxirane ring. In addition, high molar ratio of formic acid can cause hydrolysis which tends to decrease $\% \mathrm{RCO}^{21}$

\subsection{Optimum Reaction Conditions}

Based on the reported results, optimisation of the $\%$ RCO parameters was carried out using a numerical optimisation method. The optimum reaction condition calculated on the $\% \mathrm{RCO}$ for oleic acid epoxidation were operating temperature of $318 \mathrm{~K}$ and unsaturation molar ratio of formic acid and hydrogen peroxide of 1.64 and 2.0, respectively. The amount of \%RCO of predicted and experimental at optimum conditions is indicated in Table 5.

Table 5. Validation of optimum operational conditions

$$
\begin{aligned}
& \begin{array}{|c|c|c|}
\hline \multicolumn{3}{|c|}{\text { \%RCO }} \\
\hline \text { Predicted } & \text { Experimental } & \text { Errors } \\
\hline 84.7229 & 80.5538 & 4.9 \\
\hline
\end{array} \\
& \% \text { errors }=\frac{\text { predicted }- \text { experimental }}{\text { predicted }} \cdot 100 \\
& \% \text { errors }=\frac{84.7229-80.5538}{84.7229} \cdot 100=4.9 \%
\end{aligned}
$$

Comparing the experimental and predicted results it can be seen that the error between the experimental and predicted values is about $4.9 \%$ (Eq. 5). Therefore, it can be concluded that generated model has sufficient accuracy to predict the amount of \%RCO. The optimum conditions underwent confirmation test in order to study the sole effect of temperature, unsaturation of formic acid to oleic 
acid and molar ratio of hydrogen peroxide to oleic acid toward \% RCO.

\subsection{Validation Test}

The properties of each chemical were examined by Fourier Transform Infrared (FTIR) spectroscopy. FTIR was used to determine the $\mathrm{C}=\mathrm{C}$ double bonds in the oleic acid and the formation of an oxirane ring in epoxidized oleic acid and to identify the formation of alcohol groups ( $\mathrm{OH}$ groups), long chain hydrocarbon groups and the opening oxirane content in polyol. The FTIR spectrum for these chemicals is shown in Fig. 6. According to the graph, double bond of oleic acid which can be detected at the wavelength of $2980 \mathrm{~cm}^{-1}$, disappeared when epoxide groups are formed. The functional groups of oxirane ring opening $(\mathrm{C}-\mathrm{O}-\mathrm{C})$ was detected at the wavelength of $1340 \mathrm{~cm}^{-1}$. $^{22}$ Besides, alcohol groups $(\mathrm{OH})$ and groups of polyols are present at the wavelengths of 3440 and $816 \mathrm{~cm}^{-1}$, respectively. The polyols groups were obtained after degradation of oxirane ring occurred at the wavenumber of $1340 \mathrm{~cm}^{-1}$.

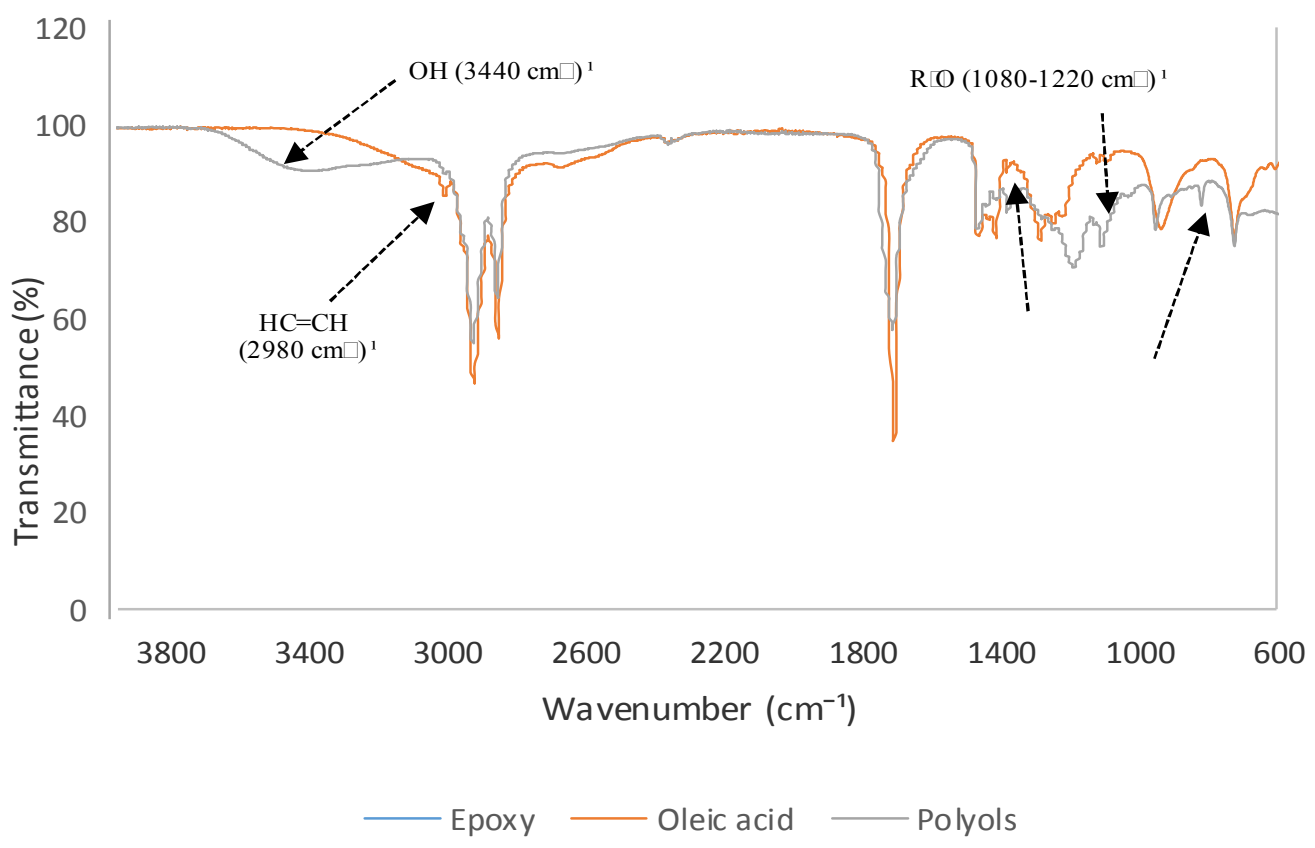

Fig. 6. FTIR combination of oleic acid, epoxide and polyols

\section{Conclusions}

The investigation of optimization involves three parameters: temperature, molar ratio of formic acid to oleic acid and of hydrogen peroxide to oleic acid. A set of 20 experiments was run to determine the percentage of RCO and to identify the optimum values of temperature, molar ratio of formic acid and hydrogen peroxide $318 \mathrm{~K}, 1.64: 1$ and 2.0:1, respectively. Linear regression was applied to ensure success relationship between the predicted and the actual ones. The value of $\mathrm{R}^{2}$ was 0.9958 which implies that $99.58 \%$ of actual data agreed well with the predicted data. Besides, analysis of variance (ANOVA) was used to identify the significant parameters and sources of model which involved linear, square and two-way interaction. All the parameters and models were significant because of satisfactory $p$-value, which is less than 0.05 for linear model and 0.0001 for the square and two-way interactions models. The optimum reaction conditions were successfully obtained by RSM. FTIR analysis confirmed the formation of epoxy functional at the wavelength of $1340 \mathrm{~cm}^{-1}$. Also, formation of polyols from epoxidized oleic acid under optimum conditions were proven by FTIR analysis at the wavelength of $816 \mathrm{~cm}^{-1}$.

\section{References}

[1] Taude, Saurabh; Patnaik, M.; Bhagt, S.L.; Renge, V.C. Epoxidation of Vegetable Oils: A Review. Int. J. Adv. Eng. Technol. 2011, II, 491-501.

[2] Bauman, Z.A. Natural History of Evil; Polity Press, 2011.

[3] Hong, L.K.; Yusop, R.M.; Salih, N.; Salimon, J. Optimization of the in-situ Epoxidation of Linoleic Acid of Jatropha Curcas Oil with Performic Acid. Malaysian J. Anal. Sci. 2015, 19, 144-154.

[4] Lu, H.; Sun, S.; Bi, Y.; Yang, G. Enzymatic Epoxidation of Biodiesel Optimized by Response Surface Methodology. African J. 
Biotechnol. 2012, 11, 12356-12363. https://doi.org/10.5897/AJB11.3831

[5] Khoon Poh, A.; Choy Sin, L.; Sit Foon, C.; Cheng Hock, C. Polyurethane Wood Adhesive from Palm Oil-Based Polyester Polyol. J. Adh. Sci. Technol. 2014, 28, 1020-1033.

https://doi.org/10.1080/01694243.2014.883772

[6] Hatchett, D.W., Kodippili, G., Kinyanjui, J.M.; Benincasa, F.; Sapochak, L. FTIR Analysis of Thermally Processed PU Foam. Polym. Degrad. Stab. 2005, 87, 555-561.

https://doi.org/10.1016/j.polymdegradstab.2004.10.012

[7] Alagi, P.; Ghorpade, R.; Jang, J.H.; Patil, C.; Jirimali, H.; Gite V.; Hong, S.C. Functional Soybean Oil-Based Polyols as Sustainable Feedstocks for Polyurethane Coatings. Ind. Crops Prod. 2018, 113, 249-258. https://doi.org/10.1016/j.indcrop.2018.01.041 [8] Boustead, I. Eco-profiles of the European Plastics Industry: Polyether Polyol.; a Report for Plastics Europe; PlasticsEurope: Brussels, March 2005.

[9] Santacesaria, E.; Tesser, R.; Di Serio, M.; Turco, R.; Russo, V.; Verde, D. A biphasic Model Describing Soybean Oil Epoxidation with $\mathrm{H}_{2} \mathrm{O}_{2}$ in a Fed-Batch Reactor. Chem. Eng. J. 2011, 173, 198209. https://doi.org/10.1016/j.cej.2011.05.018

[10] Jalil, M.J.; Mohamed, N.; Jamaludin, S.K.; Som, A.M.; Mohamad Daud, A.R. Epoxidation of Palm Kernel Oil-Based Crude Oleic Acid. Adv. Mater. Res. 2014, 906, 125-130.

https://doi.org/10.4028/www.scientific.net/AMR.906.125 [11] Derawi, D.; Salimon, J. Optimization on Epoxidation of Palm Olein by Using Performic Acid. J. Chem. 2010, 7, Article ID 384948. https://doi.org/10.1155/2010/384948

[12] Rama Rao, S., Padmanabhan, G. Application of Taguchi Methods and ANOVA in Optimization of Process Parameters for Metal Removal Rate in Electrochemical Machining of $\mathrm{Al} / 5 \% \mathrm{SiC}$ Composites. Int. J. Eng. Res. 2012, 2, 192-197.

[13] Amini, M.; Younesi, H.; Bahramifar, N.; Zinatizadeh, A.A.; Ghorbani F.; Daneshi, A.; Sharifzadeh, M. Application of Response Surface Methodology for Optimization of Lead Biosorption in an Aqueous Solution by Aspergillus Niger. J. Hazard. Mater. 2008, 154, 694-702. https://doi.org/10.1016/j.jhazmat.2007.10.114 [14] Kim, H.K.; Kim J.G.; Cho J.D.; Hong J.W. Optimization and Characterization of UV-Curable Adhesives for Optical Communications by Response Surface Methodology. Polym. Test. 2003, 22, 899-906. https://doi.org/10.1016/S0142-9418(03)00038-2 [15] Muthukumar, M.; Mohan, D.; Rajendran, M. Optimization of Mix Proportions of Mineral Aggregates Using Box Behnken Design of Experiments. Cem. Concr. Compos. 2003, 25, 751-758. https://doi.org/10.1016/S0958-9465(02)00116-6

[16] Dinda, S.; Patwardhan, A.V.; Goud, V.V.; Pradhan, N.C. Epoxidation of Cottonseed Oil by Aqueous Hydrogen Peroxide Catalysed by Liquid Inorganic Acids. Biores. Technol. 2008, 99 , 3737-3744. https://doi.org/10.1016/j.biortech.2007.07.015 [17] Lee, P.L.; Wan Yunus, W.M.Z.; Yeong, S.K.; Dzulkefly Kuang, A.; Lim, W.H. Optimization of The Epoxidation of Methyl Ester of Palm Fatty Acid Distillate. J. Oil Palm Res. 2009, 21, 675-682.
[18] Derouet D. and Brosse J.: Comparative Study of The Epoxidation of Natural and Synthetic Rubber Latices. J. Rubb. Res., 2006, 9 (1), 1-20.

[19] Statistik Indonesia 2014; Katalog BPS, Vol. XXXIII, No.2, pp 81-87.

[20] Mushtaq, M.; Tan, I.M.; Nadeem, M.; Devi, C.; Lee, S.Y.C.; Sagir M.; Rashid, U. Epoxidation of Methyl Esters Derived from Jatropha Oil: An Optimization Study. Grasas y Aceites, 2013, 64, 103-114. https://doi.org/10.3989/gya.084612

[21] Fong, M.N.F.; Salimon, J. Epoxidation of Palm Kernel Oil Fatty Acids. J. Sci. Technol. 2012, 4, 87-98. Retrieved from https://penerbit.uthm.edu.my/ojs/index.php/JST/article/view/605 [22] Jalil, M.J.; Jamaludin, S.K; Rafizan, A.; Daud M. Degradation Oxirane Ring Kinetics of Epoxidized Palm Kernel Oil-Based Crude Oleic Acid. Chem. Chem. Technol., 2018, 12, 296-299.

https://doi.org/10.23939/chcht12.03.296

Received: July 12, 2019 / Revised: October 10, 2019 / Accepted: February 22, 2020

\section{ОПТИМІЗАЦІЯ ПРОЦЕСУ ЕПОКСИДУВАННЯ ПАЛЬМОВОЇ ОЛЕЇНОВОЇ КИСЛОТИ ДЛЯ ОДЕРЖАННЯ ПОЛІОЛІВ}

\begin{abstract}
Анотація. За допомогою методу крутого сходження (методу RSM) на основі трирівневого трифакторного експерименту (CCD) проведено оптимізацію процесу епоксидування. 3 метою визначення оптимальних умов реакиї для отримання поліолів вивчено відгук відносного вмісту оксирану (\%RCO). Прогнозоване значення моделі (85\%) відмінно узгоджувалось з експериментальним значенням (81\%). Встановлено, що всі параметри (температура, молярне співвідношення мурашиної кислоти до олеїнової кислоти та пероксиду водню до олеїнової кислоти) мали суттєвий вплив на хід реакиї епоксидування $(p<0,05)$. Показано, щзо взаємодія між усіма параметрами має велике значення $i$ при $p<0,0001$. За методом RSM встановлені оптимальні умови реакиї: температура $318 \kappa$, молярне співвідношення мурашиної кислоти до олеїнової кислоти 1,64:1 та молярне співвідношення пероксиду водню до олеїнової кислоти 2:1. Епоксидування пальмової олеїнової кислоти здійснювалося з використанням in situ пероксимурашиної кислоти. 3 а допомогою Фур'є-спектроскопї доведено утворення епоксидних функиіональних груп за оптимальних умов реакиї при довжині хвилі $1340 \mathrm{~cm}^{-1}$. Ця епоксидна група була використана для отримання поліолів за допомогою прочесу гідроксилювання, а функиіональна група поліолів була виявлена при довжині хвилі $816 \mathrm{~cm}^{-1}$.
\end{abstract}

Ключові слова: температура, мольне співвідночення, мурашина кислота, пероксид водню, епоксидування, поліоли. 